\title{
Prevalence of camel tuberculosis and associated risk factors in camels slaughtered at Akaki Abattoir, Ethiopia.
}

\author{
Yasmin Jibril ${ }^{1^{*}}$, Gezahegne Mamo ${ }^{2}$, Ibrahim Hanur ${ }^{1}$, Aboma Zewude ${ }^{3}$ and Gobena \\ Ameni $^{3}$ \\ ${ }^{1}$ Department of Clinical studies, College of Veterinary Medicine and Agriculture, Addis Ababa \\ University, Bishoftu, Ethiopia \\ ${ }^{2}$ Department of Microbiology, Immunology and Veterinary Public Health, College of Veterinary \\ Medicine and Agriculture, Addis Ababa University, Bishoftu, Ethiopia
}

${ }^{3}$ Aklilu Lemma Institute of Pathobiology, Addis Ababa University, Bishoftu, Ethiopia

*Corresponding author: College of Veterinary Medicine and Agriculture, Addis Ababa University, P.O. Box 34, Bishoftu, Ethiopia, Email: yasminjibril11@yahoo.com

http://dx.doi.org/10.4314/evj.v20i1.2

\begin{abstract}
A cross sectional abattoir based study was conducted from February 2014 to October, 2015 on camels slaughtered at Akaki municipality abattoir to determine the prevalence of Tuberculosis in camels and assess the association of risk factors with the prevalence of Tuberculosis in camels using single intra-dermal comparative cervical tuberculin (SICCT). Of the total of 387 camels investigated, overall camel tuberculosis prevalence of $9.82 \%$ (95\% CI: $6.84 \%-12.8 \%$ ) at a cut off value $\geq 4 \mathrm{~mm}$ and prevalence of $17.05 \%$ (95\% CI: $13.3 \%$-20.82\%) at a cut off value $\geq 2 \mathrm{~mm}$, were recorded. Pearson chi-square test reveals, there was statistically significant association of prevalence with the origin of camels at a cut off value $\geq 2 \mathrm{~mm}\left(\mathrm{X}^{2}=13.461\right.$, $\mathrm{P}=0.000)$. However, there was no statistically significant association $(\mathrm{P}>0.05)$ of risk factors of age, sex, body condition and origin of camels with the prevalence at a cut off value $\geq 4 \mathrm{~mm}$. The multivariate logistic regression analysis shows at a cut off value $\geq 4 \mathrm{~mm}$, being old aged (adjusted OR=0.999, 95\% CI: 0.450-2.22), female (adjusted $\mathrm{OR}=2.226,95 \% \mathrm{CI}$ : 0.5099-9.719) were identified as risk factors for positive tuberculin reactivity. Similarly, the multivariate analysis at a cut off value $\geq 2 \mathrm{~mm}$, showed being moderate body conditioned (adjusted OR=1.583, 95\% CI: 0.7399 3.385) was identified as risk factor for higher tuberculin reactivity. The present study aimed to determine tuberculin reactivity of camels and assess associated risk factors with the prevalence. It was concluded that Tuberculosis is an existing phenomenon in camels. It is therefore, recommended that detailed epidemiological investigations should be conducted for the better understanding of the epidemiology of the disease in camels of pastoral communities with particular emphasis to
\end{abstract}


zoonotic significance in camel rearing areas of Ethiopia.

Keywords: Akaki abattoir, Camel Tuberculosis, Ethiopia, Prevalence, Risk factors, Comparative Tuberculin testing.

\section{Introduction}

Dromedary camels (one-humped Camelus dromedarius) historically inhabiting the Middle East and the Horn of Africa, have an estimated world population of about 18 million across the arid and semi-arid environments of the African and Asian countries. In Africa the dromedary population of about 15 million accounts for about $74 \%$ of the world camel population, and of these, $60 \%$ are found in east African countries (Somalia, 6.2 million; Sudan, 2.8 million; Ethiopia, 1.7 million, Kenya, 0.9 million) (Rhodes et al., 2015).

Tuberculosis is a chronic bacterial disease in animals and humans characterized by the progressive development of specific granulomatous lesions of tubercles in affected tissues. The disease affects all age groups of susceptible hosts and is accountable for more deaths throughout the world than any other bacterial disease ever today (Omer and Gaffer, 2002). Tuberculosis in cattle and other domestic animals is above all caused by two members of Mycobacterium tuberculosis complex (MTC): M. bovis and M. caprae (Pavlik et al., 2002; Prodinger et al., 2002; Erler et al., 2004). However, occasional occurrence of tuberculosis due to $M$. tuberculosis species with concurrent tuberculous lesions has been reported in pigs (Lesslie and Brin, 1970; Popluhar et al., 1974; Flesja et al., 1978), in cattle (Popluhar et al., 1974; Schliesser, 1976; Thoen et al., 1981; Pavlik et al., 2005), in dogs (Pavlik et al., 2003) and other animals (Pavlik, 2006).

Tuberculosis is a disease that had already been diagnosed around the turn of the century in dromedaries in Egypt (Little wood, 1888; Wernery and Kaaden, 2002). Studies conducted in Egypt, Sudan, India, Somalia, Kazakhstan and Ethiopia has shown that tuberculosis is occurring in camels (Fassi Fehri, 1987). Camel TB has been described in Egypt (Mustafa, 2013), the United Arab Emirates (Kinne et al., 2006; Wernery et al., 2007; 2012), Pakistan, Kazakhstan (Elmossalami et al., 1971), Somalia, Nigeria (Abubaker et al., 2014), and Ethiopia (Mamo et al., 2009; 2011; Zerom et al., 2013). M. bovis, M. tuberculosis and Non Tuberculous Mycobacteria (NTBC) such as M. kansasii, M. aquae, M. 
fortuitum and M. smegmatis have all been isolated from Old World Camelids (OWC) as causative agents of camel TB (Kinne et al., 2006; Elmossalami et al., 1971; Mamo et al., 2011; Zerom et al., 2013, Rhodes et al., 2015).

In Ethiopia, few studies have been conducted in the epidemiological investigation of Tuberculosis and identification of the causative agents in camels (Mamo et al., 2009, 2011; Zerom et al., 2013). The present study, therefore, the first of its kind to determine the prevalence of tuberculosis in camels using comparative tuberculin testing of camels slaughtered at Akaki abattoir and assesses associated risk factors with the disease prevalence.

\section{Materials and Methods}

\section{Study area}

A cross sectional abattoir based epidemiological investigation of tuberculosis in camels was conducted from February, 2014 to October, 2015, to determine the prevalence of tuberculosis in camels and assess the associated risk factors for infection and transmission based on single intradermal comparative cervical tuberculin test, post-mortem examination and mycobcaterial culture isolation on camels slaughtered at Akaki municipality abattoir. Akaki municipality abattoir is located in Akaki town which is one of the districts of Addis Ababa, in central Ethiopia. Camels slaughtered at Akaki municipality abattoir were mainly originated from Borena and Metehara pastoral areas of Ethiopia (Figure 1). Borena is located in the Oromia National Regional State, about $600 \mathrm{kms}$ South of Addis Ababa. The climate of the Borena zone is semi arid. Metehara is also located in Oromia National Regional State, about $250 \mathrm{kms}$ East of Addis Ababa. The prevailing climate in Metehara is arid (NMSA, 1999). 


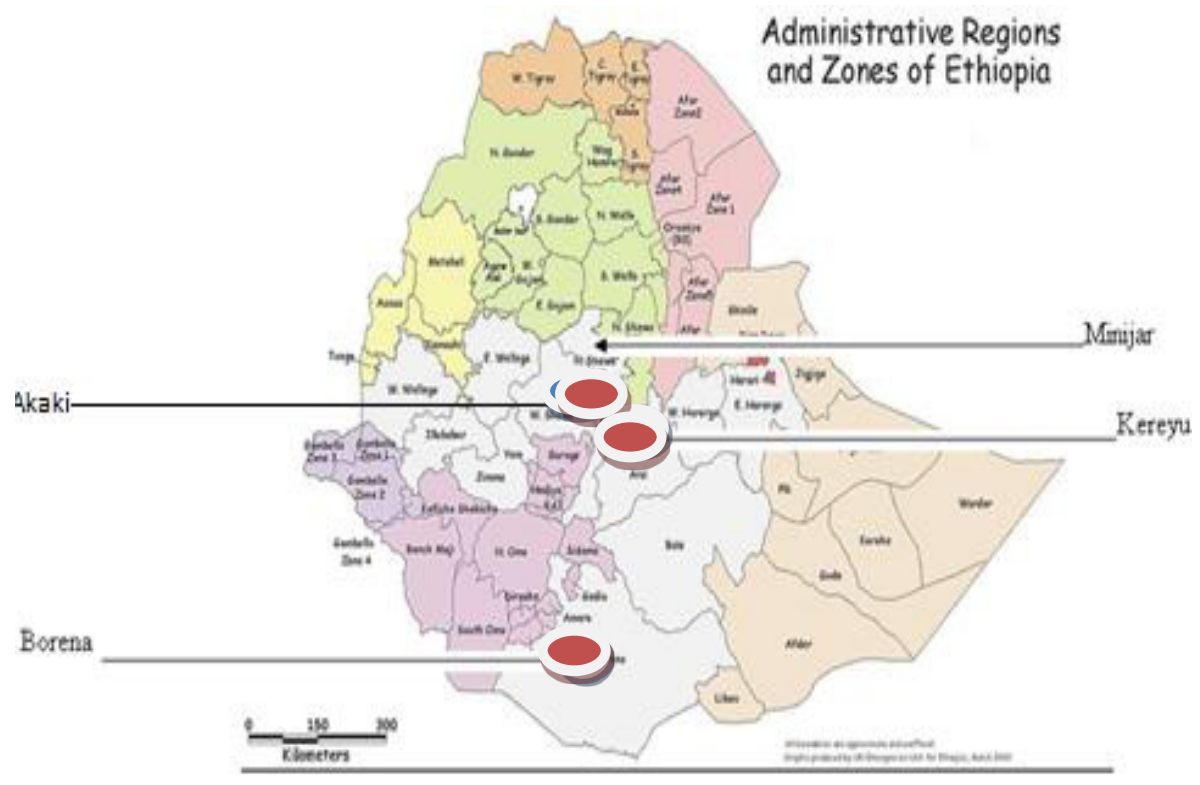

Figure 1: Map of Ethiopia with zones, showing the origin of camels (Borena and Metehara) slaughtered at the Akaki abattoir (Source: kassaye et al., 2013)

\section{Study population}

A total of 387 apparently healthy camels (347 female, 40 male) were included in this study. Frequently, older aged and unproductive female camels were slaughtered in the abattoir during our investigation. Risk factors of age, sex, body condition, and origin of the camels were recorded to assess the association of these risk factors with the prevalence of Tuberculosis. On average, camels which have stayed for at least three days in the holding pen of the abattoir were considered to facilitate re-measuring of Tuberculin skin reaction after 72 hours of injection.

\section{Sample size determination}

For cross sectional abattoir investigation to determine the prevalence of $\mathrm{Tu}$ berculosis in camels using single intra-dermal comparative cervical tuberculin (SICCT) test, the formula for random sampling of Thrusfied (2005) were used. For this, 95\% confidence level, 5\% desired absolute precision, and expected prevalence of $10.4 \%$ (Mamo et al., 2011) was considered. Thus, the sample size 
of 198 camels was calculated; however, to increase the precision of sample estimates, sample size was increased to 387 as much more than the calculated sample size.

\section{Single Intradermal Comparative Cervical Tuberculin Test (SICCT)}

Single Intra-dermal comparative cervical tuberculin (SICCT) was carried out by injecting both bovine purified protein derivative (PPD) and avian PPD (Observe $^{\mathrm{TM}}$ bovine and avian tuberculin, Asure Quality Company, Mt. Wellington, Auckland, New Zealand). Two sites on the skin of the mid-neck of the camel, 12 $\mathrm{cm}$ apart, were shaved, and skin thickness was measured with a caliper. One site was injected with an aliquot of $0.1 \mathrm{ml}$ of $3000 \mathrm{IU} / \mathrm{ml}$ bovine PPD into the dermis, and the other was similarly injected with $0.1 \mathrm{ml}$ of $2,500 \mathrm{IU} / \mathrm{ml}$ avian PPD (Figure 2).

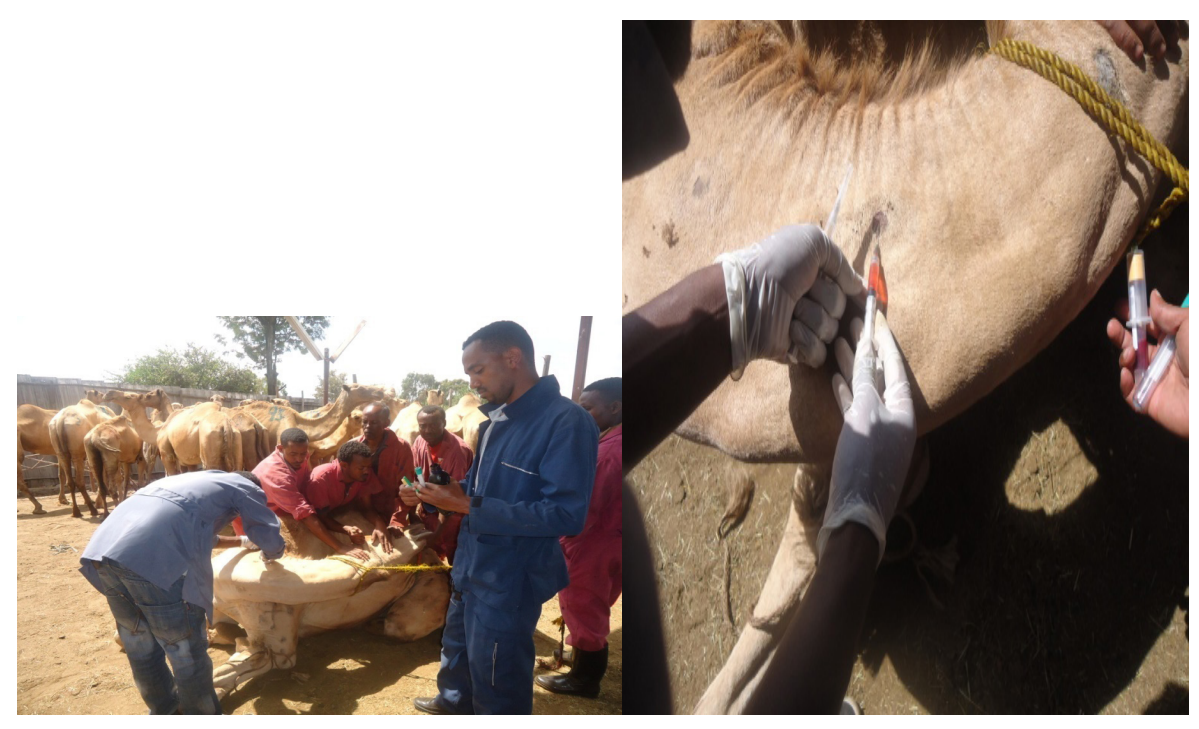

Figure 2: Pictures showing abattoir workers along with field assistants while restraining camels for comparative tuberculin testing and sample collection at Akaki abattoir.

After 72 hours, the skin thickness at the injection sites was measured and recorded. Results were interpreted according to the recommendations of the Office International des Epizooties (OIE, 2009) at $\geq 4 \mathrm{~mm}$ cut-off and also at $\geq 2$ 
mm cut-off (Ameni et al., 2008). Thus, at cut-off $\geq 4 \mathrm{~mm}$, if the increase in skin thickness at the injection site for bovine PPD (PPD-B) was greater than the increase in skin thickness at the injection site for avian PPD (PPD-A) and; If PPD-B minus PPD-A was $<4 \mathrm{~mm}$ or $\geq 4 \mathrm{~mm}$, the animal was classified as negative, or positive for BTB, respectively. At cut-off $\geq 2 \mathrm{~mm}$, if the difference between $B$ and $A$ was $\geq 2 \mathrm{~mm}$, the animal was considered as positive, while if the difference is $<2 \mathrm{~mm}$, the animal was considered as negative. When the change in skin thickness was greater at PPD-A site, the animal was considered positive for Mycobacterial species other than Mycobacterium tuberculosis complex.

\section{Data analysis}

Data collected for the study were analyzed using STATA (Intercooled STATA version 12, Stata Corp., Collage station, TX). Statistical tests such as descriptive statistics, Pearson chi-square test, and multivariate logistic regression, were applied to determine prevalence of Tuberculosis in camels, assess association of risk factors considering statistical significance at $95 \%$ confidence level and $\mathrm{P}$ value of 0.05 .

\section{Results}

Single intra-dermal comparative cervical tuberculin (SICCT) test result indicated that overall apparent prevalence of $9.82 \%$ (95\% CI: $6.84 \%-12.8 \%)$ at a cut-off value $\geq 4 \mathrm{~mm}$ and prevalence of $17.05 \%$ (95\% CI: $13.3 \%$-20.82\%) at a cut off value $\leq 2 \mathrm{~mm}$. Pearson chi-square test showed there was no statistically significant association $(\mathrm{P}>0.05)$ of risk factors of age, sex, body condition, and origin of camels at a cut off value $\geq 4 \mathrm{~mm}$ although higher prevalence of $10.37 \%$ and $5.0 \%$ was recorded in female and male camels, respectively. However, statistically significant association $\left(\mathrm{X}^{2}=13.461, \mathrm{P}=0.000\right)$ was observed for the origin of camels with the prevalence at a cut off value $\geq 2 \mathrm{~mm}$ (Table 1 ). 
Table 1: Association of risk factors of camels with tuberculin positive reactivity at a cut off value $\geq 4 \mathrm{~mm}$ and at a cut off value $\geq 2 \mathrm{~mm}$

\begin{tabular}{|c|c|c|c|c|}
\hline Variables & $\begin{array}{l}\text { No. Exam- } \\
\text { ined }(\%)\end{array}$ & $\begin{array}{l}\text { No. Positive } \\
(\%)\end{array}$ & COR (95\% CI) & AOR (95\% CI) \\
\hline \multicolumn{5}{|l|}{ Age } \\
\hline$\leq 6$ years & $93(23.5 \%)$ & & & \\
\hline \multirow[t]{4}{*}{$\geq 7$ years } & $294(76.5 \%)$ & $9(9.68)$ & 1 & 1 \\
\hline & & $29(9.86)$ & & \\
\hline & & & $1.0213(0.4649-$ & $0.9998(0.4503-$ \\
\hline & & & 2.244 & $2.220)$ \\
\hline \multicolumn{5}{|l|}{ Sex } \\
\hline Male & $40(10.3 \%)$ & & & \\
\hline \multirow[t]{3}{*}{ Female } & $347(89.7 \%)$ & $2(5.00)$ & 1 & 1 \\
\hline & & $36(10.37)$ & & \\
\hline & & & $\begin{array}{c}2.1994(0.5092- \\
9.500)\end{array}$ & $2.226(0.5099-9.719)$ \\
\hline \multicolumn{5}{|l|}{ Body Cond. } \\
\hline Poor & $209(54 \%)$ & & & \\
\hline Moderate & $70(18.1 \%)$ & $21(10.05)$ & $0.985(0.456-2.126)$ & $0.958(0.4401-2.088)$ \\
\hline \multirow[t]{3}{*}{ Good } & $108(27.9 \%)$ & $6(8.57)$ & 0.8267 (0.2912- & $0.8332(0.2877-$ \\
\hline & & 11(10.19) & $2.347)$ & $2.413)$ \\
\hline & & & 1 & 1 \\
\hline \multicolumn{5}{|l|}{ Origin } \\
\hline Borena & $323(83.5 \%)$ & & & \\
\hline \multirow[t]{3}{*}{ Metehara } & $64(16.5 \%)$ & $31(9.6)$ & 0.8645 (0.3629- & $(0.3339-1.940)$ \\
\hline & & $7(10.94)$ & 2.059) & 1 \\
\hline & & & 1 & \\
\hline
\end{tabular}

Note: * Chi-square and P-value with statistically significant association.

The multivariate logistic regression analysis, at a cut off value $\geq 4 \mathrm{~mm}$, being old aged (older camels) $(\mathrm{COR}=1.0214$, 95\% CI: 0.468-2.244; adjusted OR= 0.999, 95\% CI: 0.450-2.222), being female (COR= 2.199, 95\% CI: 0.5092-9.500; $\mathrm{AOR}=2.226,95 \% \mathrm{CI}: 0.5099-9.719)$. Similarly, the multivariate analysis at a cut off value $\geq 2 \mathrm{~mm}$, being moderate body conditioned (COR $=1.863,95 \% \mathrm{CI}$ : 0.8972-3.867; adjusted $\mathrm{OR}=1.583,95 \% \mathrm{CI}: 0.7399-3.385)$ were identified as risk factors for higher tuberculin reactivity (Table 2). 
Table 2: Multivariate logistic regression analysis of risk factors of camel tuberculosis with comparative tuberculin reactivity at a cut off value $\geq 4 \mathrm{~mm}$

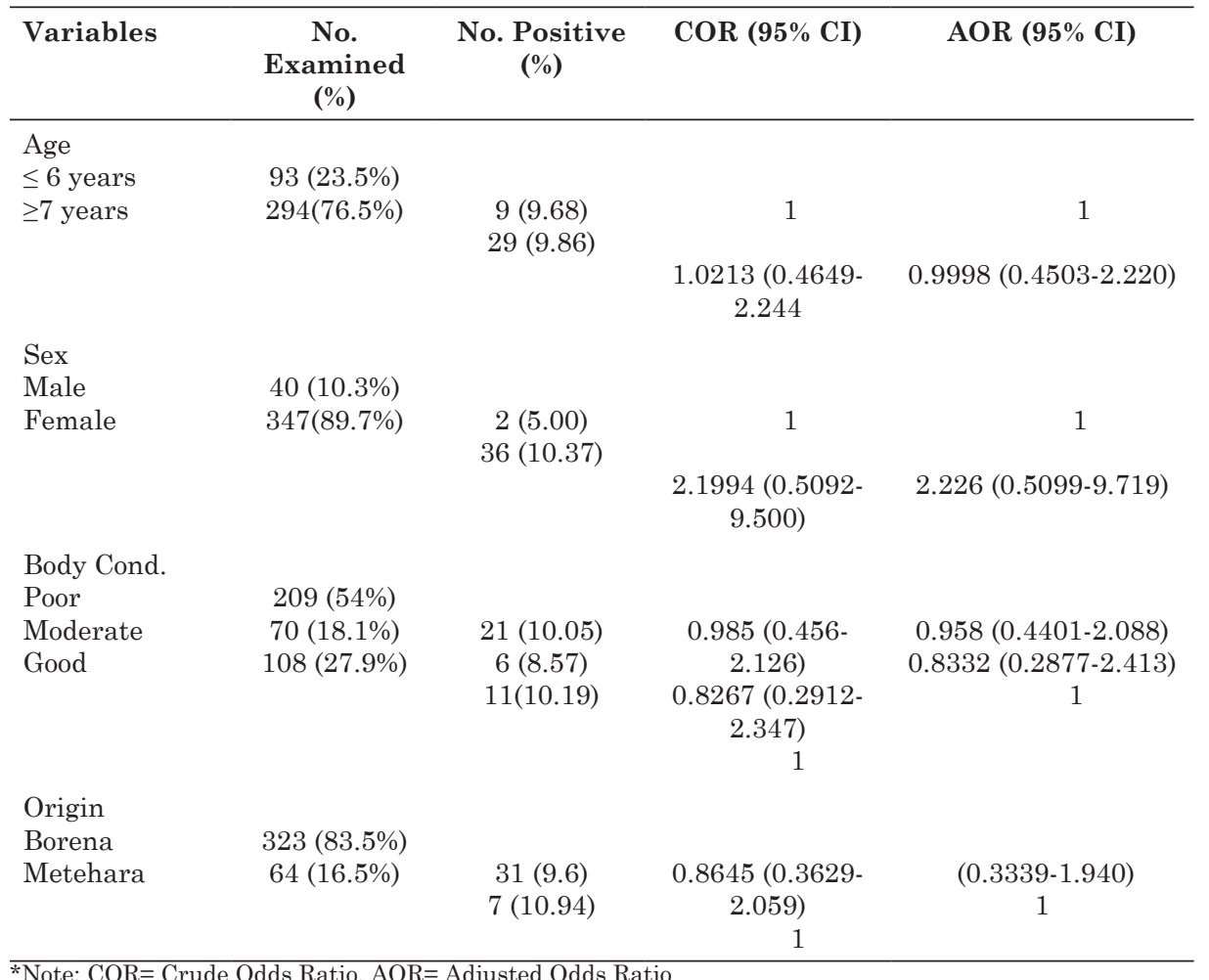

\section{Discussion}

The current study based on comparative tuberculin testing, overall prevalence of $9.82 \%$ at a cut off value $\geq 4 \mathrm{~mm}$ and prevalence of $17.05 \%$ at a cut off value $\geq 2 \mathrm{~mm}$ were recorded. The present finding at a cut of value $\geq 4 \mathrm{~mm}$ is slightly lower but comparable to the previously reported prevalence of Mamo et al. (2011) for camels of Afar, and other reports (Mamo et al., 2013). But it is higher than the reports of Mamo et al. (2009) at Dire Dawa, and Gumi et al. (2011) in Southern Ethiopia. Similarly, it is significantly higher than previously reported prevalence of some other authors at different sites in Ethiopia (Gumi et al., 2011, 2012; Tamiru et al., 2013; Admasu et al., 2014; Ameni and Aklilu, 2007; Romha et al., 2014; Nuru et al., 2015), in Zambia (Pandey et al., 2013), in Ecuador (Proano-Perez et al., 2009) in Bangladesh (Mondal et al., 2014). 
Again the current finding is higher than the findings of Kassaye et al. (2013) and Feyissa et al. (2014) for camels at Akaki and Easten part of Ethiopia, respectively. It is comparably higher than the incidence reported for camels in Egypt by Manal et al. (2008). At the same cut off value $\geq 4 \mathrm{~mm}$, the present finding is lower than previously reported prevalence of $23.7 \%$ and $30.0 \%$ in Ethiopia (Kebede et al., 2008; Firdesa et al., 2012) and in India with 14.3\% (Thakur et al., 2010). It is also lower than that of Abubakar et al. (2014) for camels slaughtered at Kano abattoir, Nigeria. Similarly, the current prevalence of $17.05 \%$ at a cut off value $\geq 2 \mathrm{~mm}$ is in close agreement with that of Mamo et al. (2013) in Afar. But significantly higher than some other previously reported prevalence in different sites of Ethiopia (Tamiru et al., 2013; Gumi et al., 2011; Tschopp et al., 2011). These variations might be due to variations in the study population, study site, animal species, production system, management factors, environmental factors, study design, methodology, and sample size factors. In the present study, prevalence of $9.68 \%$ and $9.86 \%$ was recorded for young adult ( $\leq 6$ years) and older aged ( $\geq 7$ years) camels, respectively at a cut off value $\geq 4 \mathrm{~mm}$ and prevalence of $19.35 \%$ and $16.33 \%$ for young adult ( $\leq 6$ years) and older aged ( $\geq 7$ years) camels, respectively at a cut off value $\geq 2 \mathrm{~mm}$, respectively. Age as a risk factor, there was no statistically significant association $(\mathrm{P}>0.05)$ between Tuberculosis prevalence and age categories.

This finding was in agreement with that of Nuru et al. (2015) for cattle in Amhara region, and Kasaye et al. (2013) for camels at Akaki, Central Ethiopia and some other previous studies in Ethiopia (Kebede et al., 2008; Admasu et al., 2014). However, some other previous studies in Ethiopia (Ameni and Aklilu, 2007; Kebede et al., 2008; Gumu et al., 2011; Mamo et al., 2013), from Ecuador (Proano-Perez et al., 2009) and study from India (Thakur et al., 2010) reported significant association of age with positive tuberculin reactivity. In the current study age variation in prevalence might be due to the proportion or the number of camels investigated in the age categories where large number of older camels (76.5\%) was slaughtered in the abattoir during the study period than younger age categories (23.5\%). Despite very few numbers of young camels in this study, tuberculin reactors were relatively higher than reactors among old age categories of camels investigated.

About $89.7 \%$ of the camels investigated were females. The prevalence at the two cut off values were not statistically significant $(\mathrm{P}>0.05)$. The current finding is in agreement with that of Nuru et al. (2015). However, an Ethiopian 
study (Zeru et al., 2014) reported significant association of sex with positive skin reactivity. In the current study, there was large number of unproductive females and older age camels which were slaughtered during the investigation. Moreover, only very few number of male camels were slaughtered that might attribute to the variation in prevalence record between males and females at a cut off value $\geq 2 \mathrm{~mm}$ although this was not statistically significant ( $\mathrm{P}>0.05$ ). The study of Abubakar et al. (2014) at Kano abattoir, Nigeria, reported higher prevalence in male camels (23.9\%) than female (21.8\%) camels using lateral flow assay and his finding was not statistically significant. As to the body condition of camels investigated, prevalence of $10.05 \%, 8.57 \%$, and $10.19 \%$ were recorded for camels with poor, moderate, and good body conditions, respectively at a cut off value $\geq 4 \mathrm{~mm}$ and this was not statistically significant ( $P>0.05$ ). However, at a cut off value $\geq 2 \mathrm{~mm}$, higher prevalence of $27.14 \%$ was observed in camels with moderate body condition than poor (13.88\%) and good (16.67\%) body conditions of camels during the investigation and this was statistically significant $\left(\mathrm{x}^{2}=6.54, \mathrm{p}=0.038\right)$ with tuberculin positive reactivity and it is in agreement with the reports of Nuru et al. (2015) and some other previous studies (kebede et al., 2008; Zeru et al., 2014) but Firdessa et al. (2012) did not report similar findings.

In the current study, about $53 \%$ of the camels were with poor body condition, $20 \%$ with moderate, and the rest $27 \%$ with good body conditions. Animals with poor body condition assumed to have association with high skin reactivity however, poor body conditioned animals have relatively weak immunological responses to TB and subsequently susceptible to infection (Griffin et al., 1993; O'Reilly and Daborn, 1995). Camels with poor body conditions might have in apparent and chronic infectious diseases like Tuberculosis and good body conditioned camels might have strong immune reaction against Tuberculosis infection. Moreover, the proportions or the number of camels in different categories was not comparable and this might have attributed to slight variation in the prevalence with body conditions although it was not statistically significant.

Majority of the camels investigated during the study were Borena camels (83.5\%) and some metehara origin camels (16.5\%). Prevalence of $9.6 \%$ and $10.94 \%$ was recorded for camels of Borena and Metehara origin, respectively at a cut off value $\geq 4 \mathrm{~mm}$ and it was not statistically significant ( $\mathrm{P}>0.05)$. However, prevalence of $13.93 \%$ for Borena and $32.81 \%$ for Metehara origin camels 
at a cut off value $\geq 2 \mathrm{~mm}$ was observed and this was statistically significant $\left(x^{2}=13.46, P=0.000\right)$. Some other recent studies reported strong association between breed type and tuberculin positive reactivity for cattle in different sites at a cut off value $\geq 4 \mathrm{~mm}$ (Admasu et al., 2014; Romha et al., 2014; Zeru et al., 2014; Nuru et al., 2015). This prevalence report was significantly higher for Metehara camels than Borena camels.

This might be probably for the reasons of the disproportionate number of camels investigated for Borena and Metehara origin where majority of the camels slaughter at Akaki abattoir during the study were Borena origin camels. Moreover, management and husbandry practices where migration, mixed livestock practices might also contribute to interspecies transmission of TB and other contagious diseases and possibly the pastoral livestock keeping in Borena and Metehara area might have some contribution to this variation in prevalence. To have a better comparison and statistical significance of origin as a risk factor of camel tuberculosis, comparable number of animals should to be taken into consideration to appreciate the significance association of origin with prevalence.

\section{Conclusion}

In the present study, the prevalence recorded was comparable to some other previous studies in different sites by different authors in Ethiopia for cattle and small ruminants and very few reports for camels. It was concluded that Tuberculosis is an existing phenomenon in camels although it was assumed that camels are resistant against varieties of diseases affecting other livestock species. It is therefore, recommended that detailed epidemiological investigations should be conducted in camel rearing pastoral communities of Ethiopia with particular emphasis to the epidemiology, molecular epidemiology of strains of Mycobacterium circulating in camels and zoonotic significance of Tuberculosis in camels where the habit of consuming raw camel milk is very common in these pastoral communities.

\section{Acknowledgements}

I would like to acknowledge the college of Veterinary Medicine and Agriculture of Addis Ababa University to persue my PhD study and for allowing me to conduct this research and the courage and friendly support of technical assistants 
at Aklilu lemma Institute of Pathobiology, Addis Ababa University, who assisted me in the conduct of tuberculin and sampling during the study at Akaki abattoir, was highly appreciated.

\section{References}

Abubakar, U.B., Kudi, A.C., Abdulkadir, I.A. and Okaiyeto, S.O., 2014. Prevalence of tuberculosis in slaughtered camels (Camelus dromedaries) at Kano abattoir, Nigeria based on lateral flow technology. J. Camel Pract. Res., 21(1), 41-45.

Admasu, P., Berihun, W. and Niguse, A., 2014. Prevalence of bovine tuberculosis in dairy cattle of Yeki district, Southern Ethiopia. Afri. J. Basic Appl. Sci., 6(5), 135140.

Ameni, G., Hewinson, G., Aseffa, A., Young, D. and Vordermeir, M., 2008. Appraisal of interpretation criteria for comparative intradermal tuberculin test for the diagnosis of bovine tuberculosis in cattle in central Ethiopia. Clin. Vaccine Immunol., 15(8), 1272-1276.

Ameni, G. and Erkihun, A., 2007. Bovine tuberculosis on small-scale dairy farms in Adama town, central Ethiopia, and farmer awareness of the disease. Rev. sci. tech. Off. int. Epiz.. 26(3), 711-719.

Elmossalami, E., Siam, M.A. and Sergany, M.E., 2010. Studies on tuberculosis like lesions in slaughtered camels. Zbl. Vet. Med. B., 18, 253-261.

Erler, W., Martin, G., Sachse, K., Naumann, L., Kahlau, D., Beer, J., Bartos, M., Nagy, G., Cvetnic, Z., Zolnir-Dovc, M. and Pavlik, I., 2004. Molecular fingerprinting of Mycobacterium bovis subsp. caprae isolates from Central Europe. J. Clin. Microbiol., 42, 2234-2238.

Fassi, F., 1987. Diseases of camels. Department of Microbiology, Institute Agronomique et Veterinaire Hassan II, B. P. 6202, Rabat (Instituts), Morocco. Rev. sci. tech. Off. int. Epiz., 6 (2), 337-354.

Feyissa, A.B., Zerom, K.G., Mussa, A., Ameni, G., and Sanni, M.A., 2014. Prevalence of bovine tuberculosis in dromedary camels and awareness of pastoralists about its zoonotic importance in Eastern Ethiopia. J. Vet. Med. Anim. Health., 6 (4), 109115.

Firdessa, R., Tschopp, R., Wubete, A., Sombo, M., Hailu, E., Erenso, G., et al., 2012. High prevalence of Bovine Tuberculosis in Dairy Cattle in Central Ethiopia: Implications for the dairy industry and public health. PLoS One, 7(12), e52851.

Flesja, K. I., Fodstad, F. and Ulvesaeter, H. O., 1978. Tuberculous lesions in lymph nodes of swine in Norwegian. Nordisk Vet. Med., 30, 71-73. 
Griffin, J., Hahesy, T., Lynch, K., Salman, M., McCarthy, J. and Hurley, T., 1993. The association of cattle husbandry characteristics, environmental factors and farmer characteristics with the occurrence of chronic bovine tuberculosis in dairy herds in the Republic of Ireland. Prev. Vet. Med., 17, 145-160.

Gumi, B., Schelling, E., Firdessa, R., Aseffa, A., Tschopp, R., Yamuah, L., et al., 2011. Prevalence of bovine tuberculosis in pastoral cattle herds in the Oromiya region, southern Ethiopia. Trop. Anim. Hlth. Prod., 43 (6), 1081-1087.

Gumi, B., Schelling, E., Erenso, G., Firdessa, R., Biffa, D., Assefa, A. et al., 2012. Low prevalence of bovine tuberculosis in Somali pastoral livestock, southeast Ethiopia. Trop. Anim. Hlth. Prod., 44 (7), 1445-1450.

Kassaye, S., Molla, W. and Ameni, G., 2013. Prevalence of camel tuberculosis at Akaki abattoir in Addis Ababa, Ethiopia. Afri. J. Microbiol. Res., 7 (20), 2184-2189.

Kebede, E., Hussien, D., Assegid, B., Wondewossen, T. and Gebeyehu, M., 2008. Status of bovine tuberculosis in Addis Ababa dairy farms. Rev. Sci tech. Off. Int. Epiz., 27(3), 915-923.

Kinne, J., Johnson, B., Jahans, K.L., Smith, N.H., Ul-Haq, A. and Wernery, U., 2006. Camel tuberculosis a case report. Trop. Anim. Health Prod., 38, 207-213.

Lesslie, I.W. and Brin, K.J., 1970. Mycobacterium avium infections in cattle and pigs in Great Britain. Tubercle., 51, 446-451.

Littlewood, W., 1888. Camel tuberculosis. Egyptian Official Gazette.

Mamo, G., Abebe, F., Worku, Y., Hussien, N., Legesse, M., Tilahun, G., et al., 2013. Bovine tuberculosis and its associated risk factors in pastoral and agropastoral cattle herds of Afar Region, Northeast Ethiopia. J. Vet. Med. Anim. Health., 5(6), 171-179.

Mamo, G., Bayleyegn, G., Sisay, T., Legesse, M., Medhin, G., Bjune, G., Abebe, F. and Ameni, G., 2011. Pathology of camel tuberculosis and molecular characterization of its causative agents in Pastoral Regions of Ethiopia. PLoS One 6:e15862

Mamo, G., Kassaye, A., Sanni, M. and Ameni, G., 2009. A cross sectional study of camel tuberculosis in Ethiopia. Bull. Anim. Hlth. Prod. Afr., 57, 13-20.

Manal, M.Y. and Gobran, R.A., 2008. Some studies on tuberculosis in Camel. Egypt J. Comp. Path. Clinic. Path., 21 (4), 58-74.

Mondal, M.A.H., Parvin, M.S., Sarker, S.C., Rahman, A.K.M.A. and Islam, M.T., 2014. Prevalence and risk factors of bovine tuberculosis in cattle in Mymensingh sadar Bangl. J. Vet. Med., 12 (2), 179-183.

Mustafa, I., 2013. Bacterial diseases of dromedaries and bacterian camels. Rev. Sci. tech. Off. Int. Epiz., 6, 391-405. 
Nuru, A., Mamo, G., Laekemariam, T., Zewde, A., Medhin, G., Rembert, P. and Ameni, G., 2015. Bovine tuberculosis and its risk factors among dairy cattle herds in and around Bahir Dar City, North west Ethiopia. Ethiop. Vet. J., 19(2), 27-40.

OIE, 2009. Camel tuberculosis. OIE manual of diagnostic tests and vaccines for terrestrial animals (mammals, birds and bees). Office International des Epizootics (OIE), Paris, France. pp. 1-16.

Omer, E. and Gaffer, J., 2002. Tuberculin sensitivity in Sudanese population in contact with Cattle. Bull. Anim. Hlth. Prod. Afr., 28, 91-96.

O’Reilly, L.M. and Daborn, C.J., 1995. The Epidemiology of Mycobacterium bovis infections in animals and man: a review. Tubercle Lung Dis.,76, 1-46.

Pandey, G.S., Hang'ombe, B.M., Mushabati, F. and Kataba, A., 2013. Prevalence of tuberculosis among southern Zambian cattle and isolation of Mycobacterium bovis in raw milk obtained from tuberculin positive cows. Vet. World., 6, 986-991.

Pavlik I., 2006. The experience of new European Union Member States concerning the control of bovine tuberculosis. Vet. Microbiol., 112, 221-230.

Pavlik I., Ayele, W.Y., Parmova, I., Melicharek, I., Hanzlikova, M., Körmendy, B., Nagy G., Cvetnic Z., Katalinic-Jankovic, V., Ocepek, M., Zolnir-Dovc, M. and Lipiec, M., 2003. Mycobacterium tuberculosis in animal and human populations in six central European countries during1990-1999. Czech Vet. Med., 48, 83-89.

Pavlik I., Bures, F., Janovsky, P., Pecinka, P., Bartos, M., Dvorska, L., Matlova, L., Kremer, K. and Van-Soolingen, D., 2002. The last outbreak of bovine tuberculosis in cattle in the Czech Republic in 1995 was caused by Mycobacterium bovis subspecies caprae. Vet. Med., 47, 251-263.

Pavlik, I., Trcka, I., Parmova, I., Svobodova, J., Melicharek, I., Nagy, G., Cvetnic, Z., Ocepek, M., Pate, M. and Lipiec, M., 2005. Detection of bovine and human tuberculosis in cattle and other animals in six Central European countries during the years 2000-2004. Vet. Med., 50, 291-299.

Popluhar, L., Haladej, S., Havelka, B. and Zubaj J., 1974. Occurrence of tuberculosis in husbandry animals in Slovakia in 1972 (in Slovak). Veterinarstvi., 24, 33-34.

Proano-Perez, F., Benitez-Ortiz, W., Celi-Erazo, M., Ron-Garrodo, L., Benitez-Capistros, R., Portaels, F., et al., 2009. Comparative intradermal tuberculin test in dairy cattle in the North of Ecuador and risk factors associated with bovine tuberculosis. Am. J. Trop. Med. Hyg., 81(6), 1103-1109.

Prodinger, W. M., Eigentler, A., Allerberger, F., Schonbauer, M. and Glawischnig, W., 2002. Infection of red deer, cattle and humans with Mycobacterium bovis subsp. caprae in western Austria. J. Clic. Microbiol., 40, 2270-2272. 
Rhodes, S., Crawshaw, T., Rea-Demenech, de la. R., Bradford, S., Lyashchenko, K. P. and Mamo, G., 2015. Mycobacterial infections in camelids. Tuberculosis, leprosy and mycobacterial diseases of man and animals. Pp. 216-234.

Romha, G., Gebreagziabher, G. and Ameni, G., 2014. Assessment of bovine tuberculosis and its risk factors in cattle and humans at and around Dilla town, Southern Ethiopia. Anim. Vet. Sci., 2(4), 94-100.

Schliesser, T., 1976. Vorkommen and Bedeutung von Mykobakterien bei Tieren. Zentralblatt fur Bakteriologie, Mikrobiologie und Hygiene, Med. Microbiol. Infect. Dises. Virol. Parasitol., 235, 184-194.

Tamiru, F., Hailemariam, M. and Terfa, W., 2013. Preliminary study on prevalence of bovine tuberculosis in cattle owned by tuberculosis positive and negative farmers and assessment of zoonotic awareness in Ambo and Toke Kutaye Districts, Ethiopia. J. Vet. Med. Anim. Health., 5(10), 288-295.

Thakur, A., Sharma, M., Katoch, V.C., Dhar, P. and Katoch, R.C., 2010. A study on the prevalence of bovine tuberculosis in farmed dairy cattle in Himachal Pradesh. Vet. World., 3(9), 409-414.

Thoen, C.O., Karlson, A.G. and Himes, E.M., 1981. Mycobacterial infections in animals. Rev. Infect. Dise., 3, 960-972.

Thrusfield, M., 2005. Veterinary epidemiology, $3^{\text {rd }}$ ed. Royal (Dick) School of Veterinary Studies University of Edinburgh, Blackwell science ltd. Pp. 228-242.

Tschopp, R., Bobosha, K., Assefa, A., Schelling, E., Habtamu, M., Iwnetu, R., et al., 2011. Bovine tuberculosis at a cattle-small ruminant-human interface in Meskan, Gurage region, Central Ethiopia. BMC Infect. Dis., 11, 318.

Warnery, U. and Kinne, J., 2012. Tuberculosis in camelids, A review. Rev. Sci. tech. Off. Int. Epiz, 31(3), 899-906.

Wernery, U., Kaaden. O.R., Kinne, J. and Bornstein, S., 2002. Infectious diseases in camelids. 2nd Ed., Blackwell Science, Berlin. Pp. 91-96.

Wernery, U., Kinne, J., Jahans, K.L., Vordermeir, H.M. Esfandiari, J., Greenwald, R., Johanson, B., Ul-Haq, A. and Lyaschenko, K.P., 2007. Tuberculosis outbreaks in a dromedary racing herd and rapid serological detection of infected camels. Vet. Microbiol., 122(1-2), 108-115.

Zerom, K., Sisay, T., Mamo, G., Bayu, Y. and Ameni, G., 2013. Tuberculosis in dromedaries in eastern Ethiopia: Abattoir-based prevalence and molecular typing of its causative agents in camels. Res. J., 109, 188-192.

Zeru, F., Romha, G., Berhe, G. Mamo, G., Sisay, T. and Ameni, G., 2014. Prevalence of bovine tuberculosis and assessment of Cattle owners' awareness on its public 
Yasmin Jibril et al.

health implication in and around Mekelle, Northern Ethiopia. J. Vet. Med. Anim. Health., 6(6), 159-167. 